DOI: $10.19195 / 2300-7729.37 .6$

\author{
EWA HETMAN
}

ORCID: 0000-0003-4031-1228

Ośrodek Informacji Naukowo-Technicznej Biblioteki Politechniki Lubelskiej

\title{
Rola biblioteki w dokumentowaniu dorobku naukowego pracowników Politechniki Lubelskiej
}

\section{Wprowadzenie}

W ostatnich kilkudziesięciu latach ogromne przeobrażenia w nauce, technice i komunikacji społecznej przyczyniły się do przyjęcia nowych ról przez biblioteki akademickie. Ich dotychczasowe funkcje zostały poszerzone o nowe zadania. Współczesne biblioteki szkół wyższych mają duży udział w tworzeniu, zarządzaniu i udostępnianiu informacji naukowej. Za pośrednictwem stron internetowych, które stanowią ich wizytówkę, możliwe jest korzystanie z katalogów online, serwisów informacyjnych, baz danych. Placówki te prowadzą również własną działalność wydawniczą, dygitalizują zbiory, tworzą biblioteki cyfrowe. Biorą udział w edukacji użytkowników, coraz częściej zajmują się działalnością promocyjną i marketingową.

W niniejszym tekście skupię się na podstawowym zadaniu biblioteki akademickiej - gromadzeniu, rejestrowaniu i udostępnianiu dorobku piśmienniczego pracowników naukowych. Nadrzędnym celem działalności bibliotek szkół wyższych jest wspieranie procesu naukowo-badawczego poprzez dokumentowanie dorobku pracowników naukowych uczelni. Działalność dokumentacyjna, w tym bibliograficzna, została włączona do obowiązków bibliotek naukowych w 1958 roku na mocy ustawy o szkolnictwie wyższym ${ }^{1}$. Kolejne akty prawne próbowały regulować sprawy bibliotek akademickich w zakresie działalności naukowej². Na-

${ }^{1}$ Ustawa z dnia 5 listopada 1958 roku o szkolnictwie wyższym, tekst jednolity, Dz.U. 1973, nr 32, poz. 191.

2 Ustawa z dnia 4 maja 1982 roku o szkolnictwie wyższym, tekst jednolity, Dz.U. 1985, nr 42, poz. 201; Ustawa z dnia 12 września 1990 roku o szkolnictwie wyższym, Dz.U. 1990, nr 65, poz. 385 . 
stępnym aktem normatywnym, który obowiązywał aż do 2018 roku, była Ustawa z 27 lipca 2005 roku Prawo o szkolnictwie wyższym. Zapis tej ustawy stawiał bibliotekę uczelnianą w centrum systemu biblioteczno-informacyjnego uczelni. Według artykułu 13 ustawy do podstawowych zadań uczelni należy między innymi ,upowszechnianie i pomnażanie osiągnięć nauki, kultury narodowej i techniki, w tym poprzez gromadzenie i udostępnianie zbiorów bibliotecznych i informacyjnych"3. Od 1 października 2018 mamy nową Ustawę 2.0 Prawo o szkolnictwie wyższym i nauce. Wprowadza ona znaczące zmiany w funkcjonowaniu i finansowaniu szkół wyższych ${ }^{4}$.

Lata pięćdziesiąte XX wieku przyniosły rozbudowę infrastruktury naukowej; powstały nowe ośrodki badawcze, szkoły wyższe, w tym uczelnie techniczne. W związku z dokonującymi się przemianami w nauce wzrosła liczba dokumentowanych publikacji. Najliczniejszą grupę stanowiły bibliografie szkół wyższych zdefiniowane jako bibliografie zespołów osobowych ${ }^{5}$.

Znaczący wzrost podmiotowych bibliografii zespołów osobowych, zwłaszcza bibliografii publikacji uczelni wyższych, miał miejsce w latach dziewięćdziesiątych ubiegłego wieku. Okres ten przyniósł dynamiczne zmiany w zakresie komunikacji naukowej. Rozpowszechnianie treści naukowej i informowanie o wynikach badań oraz ich popularyzowanie możliwe stało się dzięki Internetowi. Obok bibliografii drukowanych pojawiły się jej kontynuacje w formie elektronicznej dostępnej online. Bibliograficzne bazy danych zaczęły odgrywać coraz większą rolę związaną z potrzebami uczelni i jej pracowników. Pracownicy naukowi publikują w znaczących, wysoko punktowanych wydawnictwach. W związku z systemem oceny jednostek naukowych dużego znaczenia nabiera cytowalność uznawana za miarę poziomu wydawnictw i zamieszczanych tam publikacji. Rola bibliograficznych spisów publikacji pracowników uczelni zostaje znacznie poszerzona i zyskuje na znaczeniu. „Obecnie bibliografiom tym przypisuje się funkcje: rejestracyjno-archiwizującą, informacyjną, statystyczną, parametryczną oraz promocyjną"”.

${ }^{3}$ Ustawa z dnia 27 lipca 2005 roku Prawo o szkolnictwie wyższym, http://prawo.sejm.gov. pl/isap.nsf/download.xsp/WDU20051641365//U/D20051365Lj.pdf [dostęp: 2.09.2017].

${ }^{4}$ Ustawa z dnia 20 lipca 2018 roku Prawo o szkolnictwie wyższym i nauce, http://konstytucjadlanauki.gov.pl/content/uploads/2018/08/kdn.pdf [dostęp: 8.08.2018].

5 A. Znajomski, Bibliografie zespołów osobowych — instytucji. Stan i potrzeby, [w:] Bibliografia. Teoria, praktyka, dydaktyka, red. J. Woźniak-Kasperek, M. Ochmański, Warszawa 2009, s. 117-129; H. Hleb-Koszańska, O bibliografii dla niewtajemniczonych, Wrocław 1974, s. 65. Definicja: „Bibliografia zespołu osobowego powstaje, gdy się rejestruje dorobek zespołu osób stanowiącego określoną zbiorowość, najczęściej pracowników instytucji naukowej. Taka bibliografia świadczy z reguły o aktywności naukowej, pisarskiej personelu naukowego, dostarczając najczęściej prac o tematyce pokrywającej się ze specjalizacją owej instytucji”.

${ }^{6}$ B. Woźniak, Dokumentacja dorobku naukowego pracowników wyższych uczelni. Rola bibliotek w spoleczeństwie wiedzy, [w:] IV Wroctawskie spotkania bibliotekarzy, red. D. Dudziak, M. Ziółek, Wrocław 2014, s. 143. 


\section{Dokumentowanie dorobku pracowników Politechniki Lubelskiej — od wykazów drukowanych do elektronicznej bazy "wiedzy”}

Początki dokumentowania dorobku pracowników Politechniki Lubelskiej (PL) sięgają lat pięćdziesiątych XX wieku. Rok 1953 to czas powstania uczelni technicznej w Lublinie. Dokumentowany dorobek piśmienniczy początkowo funkcjonuje w postaci kartotek, a od 1988 roku spisy publikacji ukazują się w formie drukowanej. Układ bibliografii odzwierciedla wydziałową strukturę uczelni. Rejestrowane w niej dokumenty podzielone są na dwie grupy: 1) w porządku alfabetycznym tytuły dla wydawnictw zwartych, artykułów, redakcji, recenzji; 2) w kolejności numerów dla zgłoszeń patentowych, opisów wynalazków i wzorów użytkowych. Prace poszczególnych autorów pogrupowane są w obrębie wydziałów w porządku alfabetycznym nazwisk autorów. Do każdej publikacji przypisany jest jeden pełny opis. W wypadku prac wieloautorskich znajduje się on przy nazwisku pierwszego autora. Dla współautorów istnieją odsyłacze do numeru pozycji o pełnym opisie. Bibliografię w formie drukowanej wydawano od 1988 do 2008 roku za okres 1984-2005. Jednocześnie w 1995 roku udostępniono elektroniczną bazę Publikacje Pracowników PL (od 1996 roku dostępna online) ${ }^{7}$. Motywacją do jej powstania było przyspieszenie prac związanych z rejestracją coraz większej liczby publikacji oraz nowych typów dokumentów. W bazie rejestrowane są: artykuły, fragmenty, hasła, komunikaty, książki, patenty, preprinty, recenzje, referaty, referaty wygłoszone, zeszyty. Zasięg chronologiczny bibliografii obejmuje lata 1990-2010. Opisy bibliograficzne dodatkowo wzbogacono o abstrakty. Baza daje również możliwość wydruku listy publikacji dla konkretnej jednostki i autorów.

W związku z oceną parametryczną jednostek naukowo-badawczych zainteresowanie środowisk naukowych bibliografią rośnie. Biblioteka PL w 2011 roku udostępniła bazę bibliograficzno-bibliometryczną Publikacje Pracowników Politechniki Lubelskiej ${ }^{8}$. To system autorski napisany przez specjalistę IT (w wolnym oprogramowaniu - framework Django w języku programowania Python). W skład systemu wchodzą: moduł prezentacji (dla użytkowników), moduł administratora (dla redaktorów i korektorów) oraz moduł raportów. Na głównej stronie bazy znajdują się zakładki do wyszukiwania, przeglądania oraz do celów statystycznych (,Szukaj”, „Przeglądaj”, „Raporty”). Wyszukiwanie możliwe jest przez: nazwę autora, tytuł publikacji, tytuł źródła (czasopisma, książki), jednostkę organizacyjną. Formularz wyszukiwania pozwala zawężać wyniki do roku wydania i typu publikacji. Przeglądać można w porządku alfabetycznym: tytuły publikacji, wykaz autorów, wykaz jednostek organizacyjnych, czasopisma z punk-

\footnotetext{
7 Publikacje Pracowników PL z lat 1990-2010, http://publikacje.pollub.pl/ [dostęp: 2.10.2017].

8 Publikacje Pracowników Politechniki Lubelskiej, http://pub.pollub.pl/ [dostęp: 9.10.2017].
} 
tacją MNiSW i z Impact Factor (IF). Funkcje statystyczne i sprawozdawcze pełni moduł Raporty, który umożliwia automatyczne generowanie statystyk zbiorczych dla całej uczelni, jej jednostek i indywidualnych autorów. Tabelaryczne zestawienia zawierają dane dotyczące liczby autorów, publikacji ogółem, w tym publikacji z IF, publikacji z listy MNiSW oraz będących efektem współpracy z zagranicą.

$\mathrm{Z}$ chwilą zainstalowania modułu bibliograficznego rozpoczęto wprowadzanie opisów bieżących publikacji pracowników uczelni, to jest od 2011 roku. Część retrospektywną bibliografii zamieszczono na stronie bazy w odsyłaczu Publikacje Pracowników PL z lat 1990-2010. W trosce o kompletność bibliografii pracowników, na wniosek dyrekcji Biblioteki i władz PL, ustalono zasady współpracy z kierownikami jednostek. Nieodzowne stały się wewnętrzne regulacje — zarządzenia Rektora. Ostatnie zarządzenie z 23 stycznia 2013 toku regulujące zasady dokumentowania dorobku naukowego w sposób jasny podkreśla znaczenie bazy. Punkt 1 paragrafu 4 mówi: „W okresowej ocenie pracowników i jednostek organizacyjnych Politechniki Lubelskiej uwzględniony będzie wyłącznie piśmienniczy dorobek naukowy udokumentowany w bazie Publikacje pracowników Politechniki Lubelskiej"9.

Pracownicy naukowi i doktoranci zobowiązani są dostarczać materiały do bibliotek wydziałowych oraz do Oddziału Informacji Naukowej z możliwością przesłania danych o dokumencie na adres e-mail. Opisy sporządzane są zgodnie z polskimi normami z autopsji. W wypadku braku oryginału mogą być opracowane na podstawie kopii dokumentu. Rekordy bibliograficzne dodatkowo zawierają pola dla słów kluczowych, streszczeń (polskich i angielskich) oraz adresu URL, DOI.

Rejestracji w bazie podlegają: wydawnictwa samoistne (monografie, podręczniki, skrypty) i niesamoistne (artykuły w wydawnictwach ciągłych, rozdziały, hasła w encyklopediach, słownikach, referaty), patenty i wzory użytkowe. Jeżeli chodzi o sposób publikowania, rejestrowane są dokumenty drukowane i elektroniczne (CD-ROM lub online). Zmodyfikowana bibliografia została rozszerzona o wskaźniki oceny czasopism (lista MNiSW, IF), cytowania według bazy Web of Science (WoS). Web of Science oraz Journal Citation Reports (JCR) jako produkty firmy Thomson Reuters (obecnie: Clarivate Analitics) mają kluczowe znaczenie przy ocenie jednostek naukowych. MNiSW w ankiecie jednostki za lata 2009-2012 oraz przy kolejnej ocenie 2013-2016 wymaga podawania danych według wymienionych baz ${ }^{10}$. Baza JCR jest dla pracowników naukowych źródłem informacji o wartości wskaźnika IF (decyduje o umieszczeniu czasopisma na li-

9 Zarządzenie nr R-11/2013 Rektora Politechniki Lubelskiej z dnia 23 stycznia 2013 roku w sprawie dokumentowania publikacji pracowników Politechniki Lubelskiej, https://www.pollub. pl/files/4/news/files/2590_Zarzadzenie,Nr,R-11-2013,publikacje.pdf [dostęp: 9.10.2017].

10 Rozporządzenie Ministra Nauki i Szkolnictwa Wyższego z dnia 12 grudnia 2016 roku w sprawie przyznawania kategorii naukowej jednostkom naukowym i uczelniom, w których zgodnie z ich statutami nie wyodrębniono podstawowych jednostek organizacyjnych, http://prawo.sejm. gov.pl/isap.nsf/download.xsp/WDU20160002154/O/D20162154.pdf [dostęp: 1.09.2017]. 
ście A MNiSW), na platformie WoS pracownicy poszukują zaś swoich zaindeksowanych publikacji, liczby cytowań oraz wartości indeksu Hirscha. Większość polskich bibliotek akademickich, wykorzystując te wskaźniki, może wykonywać analizy bibliometryczne dla uczelni macierzystych.

Na temat roli bibliograficznych baz publikacji pracowników uczelni w zakresie oceny parametrycznej istnieje sporo piśmiennictwa. W przeprowadzonych przez Marię Garczyńską (Biblioteka AGH) badaniach ankietowych 42\% pracowników i władz państwowych szkół wyższych pozytywnie oceniło bibliograficzne bazy i ich wykorzystanie do celów sprawozdawczych z działalności naukowej oraz oceny parametrycznej uczelni ${ }^{11}$. Nieco później badania ankietowe odnośnie do parametryzacji podjęły Iwona Socik i Anna Tonakiewicz-Kołosowska (Biblioteka Politechniki Warszawskiej). Uwzględniły one osiemnaście największych polskich bibliotek uczelni technicznych. Analiza odpowiedzi na pytania ankietowe wykazała, że tylko w sześciu z powyższych bibliotek wzorowo prowadzona jest bibliograficzna baza danych w aspekcie regulacji prawnych i potrzeb środowiska naukowego. Do bibliotek najbardziej zaangażowanych w ocenę uczelni należą: Biblioteka Politechniki Wrocławskiej, AGH, Politechniki Białostockiej, Politechniki Częstochowskiej, Uniwersytetu Zielonogórskiego oraz Politechniki Lubelskiej ${ }^{12}$.

W PL pierwsza analiza cytowań wykonana została w 1991 roku na polecenie ówczesnego Rektora ${ }^{13}$. Biblioteka zwróciła się wówczas do wyspecjalizowanych ośrodków (Biblioteki Politechniki Świętokrzyskiej i Biblioteki Politechniki Wrocławskiej) mających dostęp do bazy SCI (Science Citation Index). Wykonane analizy nie odzwierciedlały faktycznego stanu cytowań publikacji naukowych niektórych pracowników PL (powtarzające się nazwiska w podobnych dziedzinach nauk). Postanowiono samodzielnie wykonać analizę cytowań prac naukowych, opierając się na kompletnej bibliografii pracowników uczelni oraz na współpracy z kadrą naukową. Corocznie sporządzane analizy przyniosły lepsze efekty liczba cytowań znacznie wrosła ${ }^{14}$.

„Nowa” baza zaopatrzona we wskaźniki bibliometryczne i narzędzia pomocnicze usprawnia cytowalność. Dzięki połączeniu jej przez API (Application Programming Interface) z platformą WoS możliwe jest automatyczne cotygodniowe aktualizowanie cytowań zaindeksowanych tam prac pracowników PL. Opisy bi-

11 M. Garczyńska, Bibliografie publikacji pracowników państwowych szkót wyższych w Polsce w świetle badań ankietowych, „Przegląd Biblioteczny” 74, 2006, z. 1, s. 60-76.

12 I. Socik, A. Tonakiewicz-Kołosowska, Rola bibliotek akademickich w zakresie parametryzacji uczelni - badanie porównawcze na przykładzie wybranych bibliotek uczelni technicznych, „Biuletyn EBIB” 2012, nr 3 (130), http://open.ebib.pl/ojs/index.php/ebib/article/view/505 [dostęp: 1.09.2017].

13 W 1991 roku powstaje Komitet Badań Naukowych (KBN) jako naczelny organ administracji rządowej do spraw polityki naukowej i naukowo-technicznej w kraju. Od tego momentu możemy mówić o początkach „punktacji” w parametryzacji.

${ }^{14}$ H. Celoch, Analizy naukometryczne w Bibliotece Politechniki Lubelskiej, „Biuletyn EBIB” 2001, nr 11 (29), http://www.ebib.pl/2001/29/celoch.html [dostęp: 5.09.2017]. 
bliograficzne identyfikowane są po numerach DOI lub WoS. W bazie wyszczególniono wydawnictwa posiadające wartościujący wskaźnik IF. W opisie szczegółowym czasopisma posiadającego wymieniony wskaźnik umieszczono bezpośredni link do bazy JCR. Podstawą oceny parametrycznej jest Ujednolicony wykaz czasopism punktowanych (lista $A, B, C M N i S W$ ). Punktacja czasopism z wymienionych list po ukazaniu się na stronie MNiSW jest aktualizowana w bazie PL. Punkty za monografie i rozdziały nie są zapisywane w systemie, podawane są one przez Komisje do spraw Oceny na poszczególnych wydziałach.

Dodatkowo bazę połączono z aplikacją ResearcherID — ogólnodostępnym portalem dla autorów i badaczy naukowych zintegrowanym z platformą WoS. Pozwala on na identyfikację autora, stworzenie publicznego profilu, utworzenie listy własnych prac naukowych i zarządzanie nią. Ułatwia współpracę i kontakt z naukowcami na całym świecie. Dzięki zastosowaniu w bazie standardowego formatu RIS (Research Information Systems) możliwa jest wymiana danych i ich eksportowanie do innych programów referencyjnych.

Struktura bazy daje możliwości aktualizowania, uzupełniania i efektywnego wyszukiwania informacji. W ciągu kilku lat jej funkcjonowania dokonano wielu modyfikacji związanych z coraz sprawniejszym wprowadzaniem kompletnych i odpowiedniej jakości danych. Zawarte w niej informacje wykorzystywane są do oceny wewnętrznej jednostek uczelni, okresowej nauczycieli akademickich i indywidualnej pracowników starających się o awans zawodowy. Bibliograficzno-bibliometryczna baza to ważne narzędzie do parametrycznej oceny osiągnięć środowisk naukowych.

\section{Udział Ośrodka Informacji Naukowo-Technicznej w przygotowaniu publikacji naukowych do oceny parametrycznej (2013-2016)}

Kompleksowa ocena parametryczna odnosi się do jednostek naukowych. Przeprowadzana jest przez Komitet Ewaluacji Jednostek Naukowych co cztery lata. Podlegają jej jednostki organizacyjne prowadzące w sposób ciągły działalność naukowo-badawczą oraz rozwojową. Wiąże się to z kategoryzacją jednostek oraz zasadami finansowania nauki w rozumieniu Rozporządzenia Ministra Nauki i Szkolnictwa Wyższego z 29 czerwca 2015 roku w sprawie Systemu Informacji o Nauce ${ }^{15}$. Na podstawie powyższego orzeczenia dane o działalności naukowo-badawczej i jej efektach należy przekazywać do systemu POL-on (System Informacji o Nauce i Szkolnictwie Wyższym).

15 Rozporządzenie Ministra Nauki i Szkolnictwa Wyższego z dnia 29 czerwca 2015 roku w sprawie Systemu Informacji o Nauce, Dz.U. 2015, poz. 944, http://www.bip.nauka.gov.pl/g2/ oryginal/2015_07/9196d392a17bff43f33ced3017ac5a58.pdf [dostęp: 7.09.2017]. 
Obowiązek sprawozdawczy dotyczy osiągnięć naukowych powstałych po 1 stycznia 2013 roku. Uczelnie zobowiązane są (od 2015 roku) do regularnego przesyłania danych do systemu POL-on i jego modułów: Polska Baza Cytowań POL-index, Ogólnopolskie Repozytorium Prac Dyplomowych (ORPD), Polska Bibliografia Naukowa - Moduł Sprawozdawczy (PBN-S). Ograniczę się do modułu sprawozdawczego, gdzie przesyłane są tylko dane o publikacjach. Trwające prace nad nowym modułem sprawozdawczym (przygotowany przez operatora Index Copernicus, przejęty i uzupełniony o nowe funkcjonalności przez Ośrodek Przetwarzania Informacji - OPI) wpływają na zmianę organizacji pracy zespołów odpowiedzialnych za przesyłanie danych. Większości bibliotek nie omijają problemy z prawidłowym przesyłaniem informacji o publikacjach z baz lokalnych do systemu centralnego. W Bibliotece PL odpowiedzialność za poprawność przekazywanych danych do PBN-S spoczywa na informatyku oraz pracownikach Ośrodka Informacji Naukowo-Technicznej (OINT) ${ }^{16}$. Tu, ze względu na parametryzację jednostek naukowych w 2017 roku, cały wysiłek skoncentrowano na skutecznej realizacji wymogów sprawozdawczych.

Zmiany w obecnym systemie parametryzacji, wynikające z ukazujących się aktów normatywnych (projekty i rozporządzenia), wymagają ich bacznego śledzenia przez pracowników OINT. Do najważniejszych zmian należą informacje o:

— afiliacji do jednej jednostki (wydziałów w wypadku uczelni),

— otwartym dostępie do publikacji (OA),

- uwzględnieniu publikacji naukowych $\mathrm{w}$ recenzowanych materiałach z międzynarodowych konferencji naukowych zaindeksowanych w bazie Web of Science Core Collection,

— wyszczególnieniu trzech typów publikacji: artykułu, rozdziału i monografii,

— podawaniu nazwy redaktora(ów) w opisach rekordów rozdziałów z monografii,

- wprowadzeniu kategorii monografii wybitnych,

— włączeniu do oceny podręczników akademickich spełniających warunki definicji monografii naukowej,

- obowiązku podawania informacji o arkuszach wydawniczych,

— ujednoliconym wykazie czasopism za lata 2013-2016 (czasopisma, które zostały zamieszczone w co najmniej jednym wykazie obowiązującym w poszczególnych latach z tego okresu z najwyższą liczbą punktów).

W tym czasie OINT pełni rolę informatora nie tylko w zakresie danych bibliograficznych, lecz także zmian $\mathrm{w}$ systemie parametryzacji. Jednym z podstawowych zadań Biblioteki PL jest eksport informacji o publikacjach do modułu sprawozdawczego. Wszystkie wymagane przez MNiSW dane, po wielu korek-

16 Ośrodek Informacji Naukowo-Technicznej — nowa jednostka w strukturze Biblioteki PL od 2015 roku, wcześniej: Oddział Informacji Naukowej. 
tach i modyfikacjach, przekazywane są z bazy PL bezpośrednio do modułu. Eksportem/importem informacji o publikacjach w postaci wygenerowanych plików w formacie XML zajmuje się informatyk pełniący rolę głównego importera publikacji (jeden dla całej uczelni). W procesie przesyłania danych pojawiają się utrudnienia powodujące kilkukrotny transfer tych samych informacji. Wynikają one między innymi z niedoskonałości nowego systemu teleinformatycznego, jak również z tempa prac nad nim po przejęciu przez nowego operatora (OPI). W związku z tym widoczne są sprzeczności, na przykład różnice między danymi w pliku XML (niezgodność z formatem PBN-S). Dotyczą one określonej długości pól, formatu daty (różny zapis w różnych systemach) i numeru ISSN. Inne niedogodności to: dostęp do PBN-S mają tylko wyznaczeni importerzy publikacji; brak możliwości wygenerowania w odpowiednim formacie raportu (pobrania zaimportowanych danych); niemożność usuwania większej partii rekordów (tylko pojedyncze rekordy). Wymienione problemy rodzą konieczność wielokrotnych prób importowania oraz zmian w strukturze bazy lokalnej i stałego sprawdzania zawartych w niej danych. Na potrzeby sprawozdawcze w lokalnej bazie dodane zostały przez informatyka nowe pola dla określonych typów publikacji. Są to informacje o: otwartym dostępie (OA), rodzaju otwartej licencji, sposobie i czasie udostępniania publikacji, wersji tekstu. Dla publikacji zawierających materiały konferencyjne dodano pola dla: nazwy konferencji, daty jej rozpoczęcia i zakończenia, miejsca imprezy (miasto i państwo). Zamieszczono również informacje o objętości w arkuszach wydawniczych dla monografii, rozdziałów i artykułów w obcojęzycznych czasopismach niebędących na liście MNiSW. W celu uzupełniania powyższych wiadomości stworzony został specjalny Formularz do publikacji pracowników PL zamieszczony na stronie bazy ${ }^{17}$. W treści formularza autorzy zobligowani są także do podawania danych o afiliacji i miejscu zatrudnienia. Szczególnej uwagi wymagają opisy publikacji z afiliacjami do kilku instytucji (multiafiliacje). Ważną rolę odgrywa współpraca z dziekanami wydziałów, którzy ostatecznie decydują o umieszczeniu lub usunięciu publikacji z systemu sprawozdawczego.

Do 21 kwietnia 2017 roku (termin zamknięcia sprawozdawczości) wyeksportowano i zarchiwizowano w Module Sprawozdawczym PBN 5274 rekordy, w tym 3551 artykułów, 1546 rozdziałów i 177 monografii. Ten efekt jest zasługą wielu osób, jednak zasadnicza rola w przygotowaniu, weryfikacji i kontroli danych o publikacjach przypada Ośrodkowi Informacji Naukowo-Technicznej. Pracownicy ośrodka starają się $\mathrm{w}$ tym okresie pełnić funkcje doradcze i informacyjne dla wszystkich zainteresowanych systemem sprawozdawczym PBN. Uczestniczą w spotkaniach na uczelni oraz zewnętrznych szkoleniach dotyczących parametryzacji i sprawozdawczości. Wykazują się szeroką wiedzą w zakresie informacji

17 http://biblioteka.pollub.pl/sites/default/files/publikacje_pracownikow_pl_formularz.pdf [dostęp: 9.10.2017]. 
bibliograficznej, bibliometrycznej oraz znajomością aktów i przepisów prawnych (wewnętrzne zarządzenia uczelni i regulacje ministerialne). Tym samym wyraźnie widać, jak zwiększa się odpowiedzialność bibliotekarzy dokumentujących i rozpowszechniających informacje o naukowym dorobku pracowników uczelni.

\section{Podsumowanie}

Na przestrzeni lat obserwujemy ewoluowanie form dokumentowania dorobku naukowego od kartotek, poprzez wydawnictwa drukowane, do elektronicznych źródeł wiedzy. Bibliografia w „nowej” formie jest narzędziem wielofunkcyjnym. Będąc często kontynuacją poprzednich zarchiwizowanych spisów, zawiera informacje o nowo powstałych typach publikacji, jakie pojawiają się na rynku wydawniczym. Poza standardowymi danymi bibliograficznymi opisy dokumentów powiązane są z dostępem do pełnych tekstów (w bibliotekach cyfrowych, wolnym dostępie). Nowe narzędzia dokumentowania publikacji zaopatrzone we wskaźniki wartościujące służą sporządzaniu szczegółowych analiz bibliometrycznych. Bazy umożliwiają prezentację i wymianę wyników badań w Internecie oraz zarządzanie spisami publikacji (integracja z profilem ResearcherID, format RIS, menedżer bibliografii EndNote). Rejestracja opisów bibliograficznych wraz z wartościującymi wskaźnikami (punktacja MNiSW, IF) pozwala na wykorzystanie zgromadzonych danych dla potrzeb zestawień przesyłanych do MNiSW. Baza Publikacje Pracowników $P L$ dzięki swoim funkcjom stała się podstawowym narzędziem zasilającym Ankietę Jednostki OPI.

Czy w przyszłości lokalne bazy bibliograficzno-bibliometryczne będą spełniały swoje funkcje, zmodyfikowane i przystosowane do nowych wyzwań? Tego dowiemy się w najbliższych latach. Być może problem zarządzania zasobami danych stanie się centralną kwestią nauki, a dla kraju taką bazą będzie Polska Bibliografia Naukowa ${ }^{18}$.

\section{Bibliografia}

Bibliografia Publikacji Pracowników Politechniki Lubelskiej w roku 1984, red. I. Pawelec, Wydawnictwo Uczelniane PL, Lublin 1988.

Biliński L., Prawo biblioteczne na co dzień, Wydawnictwo SPB, Warszawa 2006.

Celoch H., Analizy naukometryczne w Bibliotece Politechniki Lubelskiej, „Biuletyn EBIB” 2001, nr 11 (29), http://www.ebib.pl/2001/29/celoch.html [dostęp: 5.09.2017].

Garczyńska M., Bibliografie publikacji pracowników państwowych szkół wyższych w Polsce w świetle badań ankietowych, „Przegląd Biblioteczny” 74, 2006, z. 1, s. 60-76.

18 H. Hollender, Czy repozytoria odmieniają naukę?, „Forum Bibliotek Medycznych” 9, 2016, nr 1, s. 77, http://forum.bg.umed.lodz.pl/images/forum/F17/ForumNr17.pdf [dostęp: 1.09.2017]. 
Hetman E., Pietrzyk-Leonowicz S., Baza Publikacji Pracowników Politechniki Lubelskiej jako narzędzie bibliometryczne, [w:] Zarzq̨dzanie wiedza i informacja $w$ aspekcie parametryzacji uczelni, red. nauk. D. Bubel, Wydawnictwo Politechniki Częstochowskiej, Częstochowa 2015, s. $131-143$.

Hleb-Koszańska H., O bibliografii dla niewtajemniczonych, Zakład Narodowy im. Ossolińskich, Wrocław 1974.

Hollender H., Czy repozytoria odmieniaja naukę?, „Forum Bibliotek Medycznych” 9, 2016, nr 1, s. 72-77, http://forum.bg.umed.lodz.pl/images/forum/F17/ForumNr17.pdf [dostęp: 1.09.2017].

Komperda A., Import publikacji Politechniki Wrocławskiej do Modutu Sprawozdawczego PBN sprawozdanie z realizacji zadania, „Biuletyn EBIB” 2016, nr 165, http://open.ebib.pl/ojs/index.php/ebib/article/view/434 [dostęp: 7.11.2017].

Publikacje Pracowników PL z lat 1990-2010, http://publikacje.pollub.pl/ [dostęp: 2.10.2017].

Publikacje Pracowników Politechniki Lubelskiej, http://pub.pollub.pl/ [dostęp: 9.10.2017].

Socik I., Tonakiewicz-Kołosowska A., Rola bibliotek akademickich w zakresie parametryzacji uczelni - badanie porównawcze na przyktadzie wybranych bibliotek uczelni technicznych, „Biuletyn EBIB” 2012, nr 3 (130), http://open.ebib.pl/ojs/index.php/ebib/article/view/505 [dostęp: 1.09.2017].

Woźniak B., Dokumentacja dorobku naukowego pracowników wyższych uczelni. Rola bibliotek w spoteczeństwie wiedzy, [w:] IV Wrocławskie spotkania bibliotekarzy, red. D. Dudziak, M. Ziółek, Wrocław 2014, s. 141-158.

Znajomski A., Bibliografie zespołów osobowych - instytucji. Stan i potrzeby, [w:] Bibliografia. Teoria, praktyka, dydaktyka, red. J. Woźniak-Kasperek, M. Ochmański, Wydawnictwo SBP, Warszawa 2009, s. 117-129.

\section{Akty prawne}

Rozporządzenie Ministra Nauki i Szkolnictwa Wyższego z dnia 29 czerwca 2015 roku w sprawie Systemu Informacji o Nauce, Dz.U. 2015, poz. 944, http://www.bip.nauka.gov.p1/g2/orygina1/2015_07/9196d392a17bff43f33ced3017ac5a58.pdf [dostęp: 7.09.2017].

Rozporządzenie Ministra Nauki i Szkolnictwa Wyższego z dnia 12 grudnia 2016 roku w sprawie przyznawania kategorii naukowej jednostkom naukowym i uczelniom, w których zgodnie z ich statutami nie wyodrębniono podstawowych jednostek organizacyjnych, http://prawo.sejm. gov.pl/isap.nsf/download.xsp/WDU20160002154/O/D20162154.pdf [dostęp: 1.09.2017].

Ustawa z dnia 5 listopada 1958 roku o szkolnictwie wyższym, tekst jednolity, Dz.U. 1973, nr 32, poz. 191.

Ustawa z dnia 4 maja 1982 roku o szkolnictwie wyższym, tekst jednolity, Dz.U. 1985, nr 42, poz. 201. Ustawa z dnia 12 września 1990 roku o szkolnictwie wyższym, Dz.U. 1990, nr 65, poz. 385.

Ustawa z 27 lipca 2005 roku Prawo o szkolnictwie wyższym, http://prawo.sejm.gov.pl/isap.nsf/ download.xsp/WDU20051641365//U/D20051365Lj.pdf [dostęp: 2.09.2017].

Ustawa z dnia 20 lipca 2018 roku Prawo o szkolnictwie wyższym i nauce, http://konstytucjadlanauki.gov.pl/content/uploads/2018/08/kdn.pdf [dostęp: 8.08.2018].

Zarządzenie nr R-11/2013 Rektora Politechniki Lubelskiej z dnia 23 stycznia 2013 roku w sprawie dokumentowania publikacji pracowników Politechniki Lubelskiej, https://www.pollub.pl/ files/4/news/files/2590_Zarzadzenie,Nr,R-11-2013,publikacje.pdf [dostęp: 9.10.2017]. 


\title{
Role of the library in documenting the scholarship of Lublin University of Technology academics
}

\begin{abstract}
Summary
The paper presents new functions and roles performed by Lublin University of Technology Library in context of the university parametric marks. A library has always played an important role in the scientific environment of universities. The primary aim of its activity is supporting the academics' scientific performance. It has been done by providing the documentation of their scholarship. The composites of information on publications from various sources not only register the items but also positively influence the scholarly communications by enhancing discoverability. These databases, additionally equipped with tools necessary to analyse citations, start to play a more and more important role. Our bibliographic database has been enriched recently by new parametric indicators: journal mark indicators, citations, for example, according to the Web of Science. It allows the library to support the system of evaluation of scientific institutions conducted by the Ministry of Education and Higher Education in Poland. The paper presents a description of the important role played by the Scientific and Technical Information Department at the University as the main coordinator concerning documentation and information including parametric evaluation of the university (2013-2016).
\end{abstract}

KEYWORDS: bibliography, scholarship, bibliographic database, bibliometric database, parametrization, Lublin University of Technology 